\title{
Instructions for the Use of MInCir Scale to Assess Methodological Quality in Therapy Studies
}

\author{
Instrucciones para la Utilización de la Escala MInCir para Valorar Calidad \\ Metodológica de Estudios de Tratamiento o Procedimientos Terapéuticos
}

Carlos Manterola ${ }^{*, * * * * *, * * * *}$; Ricardo Cartes-Velasquez ${ }^{* * *, * * * * *} \&$ Tamara Otzen ${ }^{* * *, * * * *, * * * * * * *}$

MANTEROLA, C.; CARTES-VELASQUEZ, R. \& OTZEN, T. Instructions for the use of MInCir scale to assess methodological quality in therapy studies. Int. J. Morphol., 33(4):1463-1467, 2015.

SUMMARY: The assessment of methodological quality (MQ) in biomedical research is an area of dynamic development over recent years globally. Understood as a complex and multidimensional construct, various groups have proposed tools for its assessment. Our team has designed and validated scales to assess MQ of therapy, diagnosis, and prognosis studies. However, as with other instruments, it is necessary to specify in detail how it is applied, in order to standardize the measurements made with this instrument. The aim of this article is to provide a guideline for the standardized application of the MInCir MQ scale for therapy or therapeutic procedure studies. A detailed description of the 3 domains and 6 items comprising the scale, specifying for each of them how to assess the characteristics and score articles on therapy or therapeutic procedures is presented. This article provides an application guideline that may help to improve interobserver and intraobserver reliability of the MInCir MQ scale for therapy or therapeutic procedures.

KEY WORDS: Investigative Techniques; Methods/epidemiology methodological studies; Therapy; Intervention studies; Evaluation Studies as Topic; Epidemiologic Studies; Evidence-Based Medicine.

\section{INTRODUCTION}

The implementation of the paradigm of evidence based clinical practice (EBCP) or tests demands the existence of biomedical research of the highest quality possible, meaning that they be internally valid (bias free) and external validity applies (Manterola, 2002). Unfortunately, with the start of this new paradigm it became evident that the quality of most published biomedical research was not suitable for use in the decision-making process (Ioannidis, 2005). However, how to assess the quality of biomedical research has not been clearly defined and there are currently many concepts, strategies and tools to conduct this process (Cascaes da Silva et al., 2013).

Generally speaking, there are two widely used and interrelated concepts for evaluating quality. The first refers to the quality of the report, which was mainly covered by the various screening guidelines or checklists listing the items that should be mentioned in research papers, according to the design they have used (Simera et al., 2010). The second concept is methodological quality (MQ), a multidimensional construct that includes aspects such as: type of design used, sample size, methodology, quality of analysis, quality of reporting, etc. (Manterola et al., 2006).

The group MInCir developed and validated a scale to assess the MQ of studies on therapy or therapeutic procedures (Manterola et al., 2003; Manterola et al., 2006; Manterola et al., 2009; Moraga et al., 2013), which has been used to measure the MQ in surgical and dental areas (Aravena et al., 2013; Cartes-Velasquez et al., 2014). Similarly, this scale has been used for conducting systematic reviews (SR) with an alternative methodology (Arias et al., 2012; Claros et al., 2007; Manterola et al., 2005a, 2005b, 2007; Moraga et al., 2014; Santander et al., 2013), allowing for the use of primary studies with different designs and evidence levels, thus overcoming the limitation of traditional methodology that only uses clinical trials (CT) as primary sources (Manterola et al., 2013).

Department of Surgery, Universidad de La Frontera, Temuco, Chile

** Center for Morphological and Surgical Studies (CEMyQ), Universidad de La Frontera, Temuco, Chile.

**** Ph.D. Program in Medical Sciences, Universidad de La Frontera, Temuco, Chile.

**** Center for Biomedical Research, Universidad Autónoma de Chile, Temuco, Chile.

****** Faculty of Dentistry, Universidad de Concepción, Concepción, Chile.

${ }^{* * * * * * *}$ Fellow Research, Universidad Científica del Sur, Lima, Perú. 
Last year the MInCir group reported the first version of the instructions for the use of the MQ MinCir scale for therapy or therapeutic procedures in order to standardize its use in research as already mentioned (Moraga et al., 2014). However, its use has highlighted the need to update the instructions and the scale itself, so as to be able to adapt to the changing reality in the area. The aim of this article is to provide a guideline for the standardized application of the MInCir MQ scale for therapy or therapeutic procedure studies.

\section{INSTRUCTIONS FOR ITS USE}

The MInCir scale to assess MQ of therapy studies consists of 3 domains with 6 items. Domain 1 evaluates the type of research design, domain 2 assigns scores to the size of population studied, including a justification factor (if the study includes a sample size calculation) and domain 3 consists of 4 items that assess the study's methodology (Table I).

The application of this instrument by the user requires critical evaluation of each of the items to assign the respective score, whose sum can give a total score between 6 and 36 points. The cut-off point to define the construct MQ (dichotomous) for these types of studies is 18 points; allowing for differentiation as adequate or high MQ when the evaluated article received a score $\geq 18$ points; and inadequate or low MQ if the score is $\leq 17$ points (Manterola et al., 2006, 2009; Moraga et al., 2013). Below is a detailed guide for each domain and item contained in the scale for a correct interpretation and subsequent implementation:

Domain 1: Study design. The type of study design must be mentioned in the "Materials and Methods" section of the article and must be the same as indicated in the summary. This is what should be valued according to the scores indicated by the scale. Thus, a individual double-blind randomized control clinical trail will be assigned 9 points. Moreover, at the lower end of the domain, a case series will be assigned only 1 point.

However, on many occasions it is difficult to clearly identify the study design, a situation that usually occurs when the authors, for various reasons, do not disclose or "make-up" the design used, for example:

Table I. MInCir scale for determining MQ for therapy or therapeutic procedure studies.

\begin{tabular}{|c|c|}
\hline Domains and items of the scale & Scoring \\
\hline \multicolumn{2}{|l|}{ Domain 1: Study design } \\
\hline Multicenter double blinding RCT $*$ & 12 \\
\hline Individual double blinding RCT * & 9 \\
\hline CT without or simple blinding, without randomization $* *$ & 6 \\
\hline Concurrent Cohort & 4 \\
\hline Case Controls and Historical Cohort Studies & 3 \\
\hline Cross Sectional Studies & 3 \\
\hline Series of Cases & 1 \\
\hline \multicolumn{2}{|l|}{ Domain 2: Population studied $\mathrm{x}$ justification factor } \\
\hline$>201$ & 6 or 12 \\
\hline $151-200$ & 5 or 10 \\
\hline $101-150$ & 4 or 8 \\
\hline $61-100$ & 3 or 6 \\
\hline $31-60$ & 2 or 4 \\
\hline$\leq 30$ & 1 or 2 \\
\hline \multicolumn{2}{|l|}{ Domain 3: Methodology } \\
\hline \multicolumn{2}{|l|}{ Objective } \\
\hline A clear and specific objective is set out & 3 \\
\hline Vague objective is set out & 2 \\
\hline No objective is set out & 1 \\
\hline \multicolumn{2}{|l|}{ Design } \\
\hline The design used is clearly mentioned & 3 \\
\hline The design used is not mentioned & 1 \\
\hline \multicolumn{2}{|l|}{ Selection criteria } \\
\hline Inclusion and exclusion criteria are described & 3 \\
\hline Inclusion or exclusion criteria are described & 2 \\
\hline Selection criteria are not described & 1 \\
\hline \multicolumn{2}{|l|}{ Sample size } \\
\hline Sample size used is justified & 3 \\
\hline Sample size used is not justified & 1 \\
\hline Final score (Domain 1 + Domain $2+$ Domain 3) & $6-36$ \\
\hline
\end{tabular}

*= Includes quasi-experimental studies and experimental studies (before and after studies). 
a) Articles in which authors do not provide an appropriate indication and description of the design used in "Material and Methods" of the study, nor in the summary (or just do not report it); so it is necessary to determine from a thorough reading of the article which design was used.

b) In other articles, the authors provide a brief description of some design features, such as: a prospective randomized study, instead of saying randomized CT; or retrospective study, instead of saying retrospective case series.

c) On other occasions, the study is not consistent with that reported by the authors. In such situations, what is seen most often is the use of a type of design with a greater level of evidence than that actually executed. For example, declaring a cohort study was carried out, when in fact it was a case series.

d) Lastly, some articles will mention a design that does not exist, e.g. "case-control cohort" or "non-concurrent prospective study cohort."

In such situations, one has to rate the design after carefully reading the article. When the type of design used is not mentioned, or nonexistent designs are mentioned, it is usually a case series, thus it is appropriate to assign a score of 1 point. If the authors report having developed a cohort study in the article, the incidence or absolute risk, relative risk and confidence intervals (it is very unlikely that a research group conducted a study with these features and would not properly report it) must appear as an outcome. It is equally acceptable to have a description of the characteristics of a design, for example: "randomized prospective study," rather than randomized CT, a situation that would warrant an allocation of 9 points.

Domain 2: Studied population. In this domain, a score must be given according to the number of patients who actually participated in the study: that is, those actually included in the analysis of the reported results. Also it should be considered whether this number of patients was estimated with a suitable statistical procedure during the planning of the study (estimate or calculation of the minimum sample size to conduct the study). This will allow applying the "justification factor" that can double the score of the domain. For example, a CT in which 400 patients were studied has at least 6 points, but if the minimum sample size for conducting the study was estimated, then 12 points will be assigned. For example, a study with 150 patients, with and without justification values, should be assigned 4 and 8 points respectively. Thus, recognizing the "justification factor" is too important, since in many cases the studies are made including only the available patients without considerations to ensure the statistical power of the results.
Domain 3: Methodology. This domain assesses four aspects of the methodology: objectives, design, selection criteria and sample size.

Item 1. Objectives: These are usually found at the end of the introduction. In some cases and depending on the standards of the journal, they could be at the beginning of the methodology or another section. There must be consistency between the objectives stated in the body text and the summary, but the latter could be in a slightly abridged version, according to the journal editorial criteria. In shorter articles, as in cases series, the objective could only be mentioned in the summary. Following this line of argument, objectives can be assessed on three levels:

1. Clear and concrete objectives: In this case, it is possible to clearly recognize what will be measured, by what means, by whom, where and the follow-up. The methodology is based on this objective. Three points are assigned.

2. Vague objectives: When any of the aforementioned elements is absent or improperly described, such as: "The aim of this study is to report our experience in...," "recent years," "compared to conventional choice," etc.; in this type of scenario it is not possible to clearly recognize the purpose of the study. Two points are assigned.

3. No objectives: These are not visible in any of the previously mentioned places. One point is assigned.

Item 2. Design: This will be assessed in the Methodology, sometimes entitled "Methods", "Materials and Methods" or "Patients and Methods." As with the objectives, the design must also be mentioned in the article's summary or even in the title. For a case report, the design may be mentioned only in the title or in the abstract. Options for this item are as follows:

1. Clearly identify the design: It is imperative that the reported design fits what was really executed. It is equally acceptable to have a description of the characteristics of a design, for example: "randomized prospective study," rather than randomized CT. Three points will be allocated.

2. Unknown design: It is not possible to identify the design or the design does not conform to what was actually executed. One point is assigned. For example, the authors report that the design is a cohort study, when in fact it is a case series.

Item 3. Selection criteria: This will be assessed in the Methodology, sometimes entitled "Methods," "Materials and Methods" or "Patients and Methods." Options for this item are as follows: 
1. Inclusion and exclusion criteria are described: These will be considered when they are clearly described by the authors. It is equally acceptable if the authors mention the inclusion criteria and declare the absence of exclusion criteria. Three points are assigned.

2. Inclusion or exclusion are described: It describes only one of the two, regardless of the location of these in "Material and Methods." Two points are assigned.

3. No selection criteria are described: The authors do not declare either. One point is assigned.

Item 4. Sample size: The sample size may or may not be stated by the authors; therefore, the options for this item are as follows:

1. Sample size is justified: In this case the estimation or calculation of sample size is reported. The other option is to justify the sample size, for example when all subjects in the universe or a target population was included. Three points are assigned.

2. Sample size is not justified: No reference to an estimate or calculation of the minimum sample size for conducting the study is mentioned. This is routine in case series. One point is assigned.

\section{DISCUSSION}

After the publication of the first version of the instructions for use of the MInCir scale to assess MQ of therapy studies (Moraga et al., 2014), and its use in many bibliometric studies and SR (Manterola et al., 2003, 2005a, 2005b, 2006, 2007, 2009; Claros et al.; Arias et al.; Moraga et al., 2013, 2014; Aravena et al.; Santander et al.; Cartes-Velasquez et $a l$. ), the need to update its instructions became obvious. The main reason for this update is to adjust to the real situations in which the MQ of therapy studies are evaluated, in order to facilitate the allocation of scores for each of the items and domains.

The main changes in this new version include:

1. A better description of the various situations in the evaluation and scoring of the items. This situation remains difficult due to the poor reporting quality and numerous misconceptions on methodological and statistical aspects in most published articles (Ioannidis; Ahmed Ali et al., 2013).

2. The removal of the maximum score of the Design item
(Domain 3) only for those items that justify the choice of design used. With the passage of time and experience gained through the application of the scale, we consider it a non-discriminating item. It is a rarity that the authors make this justification, among other reasons because the design choice may be obvious after reading the Introduction; this justification may involve exceeding the amount of words that the journal allows; this justification is rarely required by journals nor is it included in the most used reporting check lists (Simera et al.).

The development and validation of psychometric instruments is a complex process that involves several procedures (Streiner \& Norman, 2003), from the concept definition to evaluate/choice of the items that make up the scale and to check its psychometric properties in different contexts (Costa et al., 2015; Cartes-Velasquez et al.; Moraga et al., 2014). However, this process rarely focuses on the need to standardize the application of these instruments, thus avoiding measurement biases associated with the evaluator (Manterola \& Otzen, 2015). The lack of standardization of psychometric instruments clearly questions its applicability, results and conclusions drawn from these.

The MQ evaluation of biomedical research has verified that most published articles do not meet the minimum criteria to be used in EBCP(Ioannidis). However, the development of this line of research on MQ has been questioned by various inconsistencies in the way the MQ is evaluated (Armijo-Olivo et al., 2013). It is imperative that research on MQ applies the same standards of quality required by the rest of biomedical research. It is necessary to further refine the MQ measuring instruments and its applicability, as claimed by the instructions in this article. Given the dynamic nature of this line of research, it is expected that in the coming years updates will be made in order to adjust to changes in the MQ of biomedical research.

MANTEROLA, C.; CARTES-VELASQUEZ, R. \& OTZEN, T. Instrucciones para la utilización de la escala MInCiR para valorar calidad metodológica de estudios de tratamiento o procedimientos terapéuticos. Int. J. Morphol., 33(4):1463-1467, 2015.

RESUMEN: La evaluación de la calidad metodológica (CM) en la investigación biomédica es un área de desarrollo dinámico en los últimos años a nivel global. Entendida ésta, como un constructo multidimensional y complejo; diversos grupos han propuesto herramientas para su valoración. Nuestro equipo de trabajo ha diseñado y validado escalas para valorar CM de estudios de terapia, diagnóstico y pronóstico. Sin embargo, como ocurre con otros instrumentos, es necesario especificar detalladamente la forma en que se aplica, de forma tal de poder estandarizar las mediciones efectuadas con dicho instrumento. El objetivo de este artículo es detallar la aplicación de la escala MInCir de CM de estudios de terapia o procedimientos terapéuticos. De este modo, se 
presenta una descripción pormenorizada de los 3 dominios y 6 ítems que componen la escala, precisando para cada uno de ellos las características a evaluar y puntuar en los artículos primarios de terapia o procedimientos terapéuticos. Este artículo aporta una guía de aplicación que permite otorgar una adecuada confiabilidad intra e inter observador a las mediciones que se realicen aplicando la escala MInCir de terapia o procedimientos terapéuticos.

PALABRAS CLAVE: Técnicas de Investigación; Metodología; Calidad metodológica; Terapia; Tratamiento; Procedimientos terapéuticos; Estudios de evaluación; Estudios epidemiológicos; Medicina basada en evidencia.

\section{REFERENCES}

Ahmed Ali, U.; van der Sluis, P. C.; Issa, Y.; Habaga, I. A.; Gooszen, H. G.; Flum, D. R.; Algra, A. \& Besselink, M. G. Trends in worldwide volume and methodological quality of surgical randomized controlled trials. Ann. Surg., 258(2):199-207, 2013.

Aravena, T. P.; Cartes-Velásquez, R. \& Manterola, D. C. Productividad y calidad metodológica de artículos clínicos en cirugía oral y maxilofacial en Chile. Período 2001-2012. Rev. Chil. Cir., 65(5):382-8, 2013.

Arias, E.; Astudillo, P.; Manterola, C. \& Grupo MINCIR (Metodología e Investigación en Cirugía). Second neoplasm after treatment of localized prostate cancer. Actas Urol. Esp., 36(10):583-9, 2012.

Armijo-Olivo, S.; Fuentes, J.; Ospina, M.; Saltaji, H. \& Hartling, L. Inconsistency in the items included in tools used in general health research and physical therapy to evaluate the methodological quality of randomized controlled trials: a descriptive analysis. BMC Med. Res. Methodol., 13:116, 2013.

Cartes-Velásquez, R. A.; Manterola, C.; Aravena, P. \& Moraga, J. Reliability and validity of MINCIR scale for methodological quality in dental therapy research. Braz. Oral Res., pii:S1806-83242014000100232, 2014.

Cascaes da Silva, F.; Valdivia Arancibia, B. A.; da Rosa Iop, R.; Barbosa Gutierres Filho, P. J. \& da Silva, R. Escalas y listas de evaluación de la calidad de estudios científicos. Rev. Cuba. Inf. Cienc. Salud, 24(3):295312, 2013 .

Claros, N.; Manterola, C.; Vial, M.; Sanhueza, A. \& GRUPO MINCIR. Efectividad de la profilaxis antibiótica en el curso de la colecistectomía laparoscópica electiva. Revisión sistemática de la literatura. Rev. Chil. Cir., 59(5):353-9, 2007.

Costa, A. B.; Zoltowski, A. P. C.; Koller, S. H. \& Teixeira, M. A. P. Construção de uma escala para avaliar a qualidade metodológica de revisões sistemáticas. Ciênc. Saúde Coletiva, 20(8):2441-52, 2015.

Ioannidis, J. P. Why most published research findings are false. PLoS Med., 2(8):e124, 2005.

Manterola, D. C. Medicina basada en la evidencia. Conceptos generales y razones para su aplicación en cirugía. Rev. Chil. Cir., 54(5):550-4, 2002.

Manterola, D. C.; Pineda, N. V.; Vial, G. M.; Losada, M. H. \& Muñoz, N. S. Revisión sistemática de la literatura. Propuesta metodológica para su realización. Rev. Chil. Cir., 55(2):204-8, 2003.
Manterola, C.; Pineda, V. \& Vial, M. Open versus laparoscopic resection in non-complicated colon cancer. A systematic review. Cir. Esp., 78(1):2833, 2005a.

Manterola, C.; Pineda, V.; Vial, M.; Losada, H. \& Muñoz, S. Surgery for morbid obesity: selection of operation based on evidence from literature review. Obes. Surg., 15(1):106-13, 2005 b.

Manterola, C.; Pineda, V.; Vial, M.; Losada, H. \& MINCIR Group. What is the methodologic quality of human therapy studies in ISI surgical publications? Ann. Surg., 244(5):827-32, 2006.

Manterola, C.; Pineda, V.; Vial, M. \& Astudillo, P. Use of opioid analgesics in diagnosis and decision-making in patients with acute nontraumatic abdominal pain. A systematic review of the literature. Cir. Esp., 81(2):91$5,2007$.

Manterola, C.; Vial, M.; Pineda, V. \& Sanhueza, A. Systematic review of literature with different types of designs. Int. J. Morphol., 27(4):117986, 2009.

Manterola, C.; Astudillo, P.; Arias, E.; Claros, N. \& Grupo MINCIR (Metodología e Investigación en Cirugía). Systematic reviews of the literature: what should be known about them. Cir. Esp., 91(3):149-55, 2013.

Manterola, C. \& Otzen, T. Los sesgos en investigación clínica. Int. J. Morphol., 33(3):1156-64, 2015.

Moraga C., J.; Burgos D., M. E.; Manterola D., C.; Sanhueza C., A.; CartesVelásquez V., R.; Urrutia V., S. \& Grupo MINCIR (Metodología e Investigación en Cirugía). Confiabilidad de la escala MINCIR para valorar calidad metodológica de estudios de terapia. Rev. Chil. Cir., 65(3):222$7,2013$.

Moraga, J.; Manterola, C.; Cartes-Velasquez, R.; Burgos, M. E.; Aravena, P.; Urrutia, S. \& Grupo MINCIR. Instructions for the use of MINCIR scale to assess methodological quality in therapy studies. Int. J. Morphol., 32(1):294-8, 2014

Santander, A. C.; Astudillo, D. P. \& Manterola, D. C. Procedimiento de Hartmann vs resección y anastomosis primaria en peritonitis diverticular de colon izquierdo por cirugía abierta. Revisión sistemática de la literatura. Rev. Chil. Cir., 65(3):271-8, 2013.

Simera, I.; Moher, D.; Hirst, A.; Hoey, J.; Schulz, K. F. \& Altman, D. G. Transparent and accurate reporting increases reliability, utility, and impact of your research: reporting guidelines and the EQUATOR Network. BMC Med., 8:24, 2010

Streiner, D. L. \& Norman, G. R. Health Measurement Scales: A Practical Guide to Their Development and Use. 3rd ed. Oxford, Oxford University Press, 2003.

Correspondence to:

Dr. Carlos Manterola

Department of Surgery and CEMyQ

Universidad de La Frontera

Manuel Montt 112

Office 408

Temuco

CHILE

Received: 11-09-2015 Accepted: 22-10-2015

Email: carlos.manterola@ufrontera.cl 